\title{
PODJĘCIE I WZNOWIENIE POSTĘPOWANIA JAKO SPOSÓB POWROTU DO ZAKOŃCZONYCH POSTĘPOWAŃ W WYNIKU CZYNNOŚCI WYKRYWCZYCH PODEJMOWANYCH PRZEZ POLICYJNE ARCHIWA $X$
}

\begin{abstract}
Streszczenie. Instytucja wznowienia i podjęcia umorzonego postępowania przygotowawczego mają kluczowe znaczenie w zakresie możliwości powrotu do zakończonego postępowania karnego. Zasady postępowania karnego, decydujące o sposobie jego prowadzenia, w pewnych stanach faktycznych wymuszają zakończenie postępowania na danym etapie. Czasami wynika to z pojawienia się względnej, a więc usuwalnej negatywnej przesłanki procesowej, czasami zaś z niemożności wykrycia sprawców przestępstwa. Kluczowe jest zatem ustalenie, jakie są warunki powrotu do zakończonego postępowania przygotowawczego. Czy jest to możliwe? Jaki jest zakres czasowy możliwej do podjęcia decyzji? W niniejszym artykule zostaje udzielona odpowiedź na te pytania. Skoncentrowano się przy tym na procesowych warunkach dopuszczalności powrotu do postępowania karnego. Omówiono zasady dotyczące wznowienia i podjęcia umorzonego postępowania w zależności od momentu jego zakończenia, a także organy uprawnione do działania, warunki działania prokuratora, rolę i miejsce Policji w systemie podejmowania decyzji. Powyższe elementy stanowią próbę umiejscowienia tych instytucji szczególnych w systemie ujawniania starych zbrodni popełnionych przez nieujawnionych sprawców.
\end{abstract}

Słowa kluczowe: proces karny, podjęcie postępowania, wznowienia postępowania, przesłanki procesowe.

Policyjne Archiwa X, z uwagi na zakres dokonywanych ustaleń, w dużej mierze dokonują czynności procesowych lub faktycznych w postępowaniach formalnie zakończonych. Abstrahując od problematyki gromadzenia w ramach tych czynności dowodów, należy odnieść się do kwestii możliwości powrotu do postępowania. Możliwość powrotu do zakończonego postępowania karnego przewidziana jest $\mathrm{w}$ ramach dwóch podstawowych instytucji, jakimi są: podjęcie na nowo umorzonego postępowania i wznowienie umorzonego postępowania. Podkreślić należy, że istnieją też inne drogi prawne, jednak z uwagi na zawężenie przedmiotu zainteresowania w niniejszym opracowaniu do Policyjnych Archiwów $\mathrm{X}$, nie znajdą one zastosowana na tym gruncie.

* Uniwersytet Łódzki, Wydział Prawa i Administracji, Katedra Postępowania Karnego i Kryminalistyki, kurowski1977@gmail.com. 


\section{PODJECIE NA NOWO UMORZONEGO POSTĘPOWANIA}

Możliwość podjęcia na nowo umorzonego śledztwa lub dochodzenia (bez znaczenia, jaka była forma postępowania) przewidziana została w art. $327 \S 1$ ustawy z 6 czerwca 1997 r. - Kodeks postępowania karnego (t.j. Dz. U. 2017, poz. 1904 ze zm., dalej: k.p.k.). Obecne uregulowanie zostało znacząco zawężone $\mathrm{w}$ zakresie możliwości podejmowania postępowania $\mathrm{w}$ stosunku do znanego z k.p.k. z 1969 r., kiedy to ustawodawca posługiwał się pojęciem ,przesłuchania w charakterze podejrzanego" (Gaberle 1972, 182). W obecnym stanie prawym ustawodawca zdefiniował omawianą instytucję poprzez zawężenie jej działania i wyłączenie możliwości sięgania po nią w sytuacji, gdyby podjęte postępowanie miało się toczyć przeciw osobie, która w poprzednim postępowaniu występowała w charakterze podejrzanego. Z treści powołanego przepisu wynika możliwość podjęcia postępowania (Kaftal 1971a, 13) ${ }^{1}$ w następujących przypadkach:

- gdy umorzono postępowanie w sprawie,

- gdy umorzono postępowanie przeciwko określonemu podmiotowi, a podjęte toczyć się będzie przeciwko innej osobie,

- gdy umorzono postępowanie przeciwko określonemu podmiotowi, a podjęte toczyć się będzie bez imiennego oznaczenia podmiotu (Gaberle 1972, 182; Kulesza 1960, 753; Gutkowska 1977, 17-35; Kurowski i in. 2015, 3)².

Należy jednak zaznaczyć, że wymienione jako trzecia możliwość prowadzenie postępowania bez imiennego oznaczenia podmiotu nie może doprowadzić do „faktycznego wznowienia” postępowania. Dla pociągnięcia do odpowiedzialności tej samej osoby, w stosunku do której umorzono postępowanie przygotowawcze, wymagane jest zaistnienie warunków dla wznowienia postępowania, gdyż w innych sytuacjach co do tej osoby nie odżyje prawo wniesienia skargi (Kaftal 1959, 1054).

Zauważyć należy, iż podejrzanym jest osoba, co do której wydano postanowienie o przedstawieniu zarzutów albo której bez wydania takiego postanowienia postawiono zarzut $\mathrm{w}$ związku $\mathrm{z}$ przystąpieniem do przesłuchania $\mathrm{w}$ charakterze podejrzanego (art. 71 § 1 k.p.k.). Ta druga możliwość uaktualnia się w dochodzeniu (art. 325g § 1 k.p.k.) lub w ramach postępowania prowadzonego na podstawie przepisu art. $308 \S 2$ k.p.k. Obecnie nie budzi wątpliwości, iż koniecznością takiego przesłuchania $\mathrm{w}$ śledztwie jest obowiązek następczego wydania postanowienia o przedstawieniu zarzutów lub umorzenia postępowania przeciwko osobie przesłuchanej (308 § 3 k.p.k. - Grzegorczyk 1997, 65)³. Zasadniczą kwestią jest

${ }^{1}$ Należy podkreślić, że niektórzy autorzy nie podzielają stanowiska co do trzech okoliczności - np. Kaftal wskazuje tylko na dwie pierwsze okoliczności.

${ }^{2}$ Powołani autorzy wskazywali na taką możliwość rozszerzenia zakresu rozumienia pojęcia „podjęcie postępowania” w stosunku do „wznowienia”.

${ }^{3}$ Por. odnośnie do stanu prawnego sprzed nowelizacji k.p.k. z 10 stycznia 2003 r. 
rozumienie pojęcia „wydano postanowienie o przedstawieniu zarzutów”. Czy w cytowanym przepisie chodzi jedynie o ograniczenie się do wydania postanowienia, czy też winna zostać zrealizowana procedura wskazana w art. $313 \S 1$ k.p.k., a konkretyzując problem, czy możliwe jest podjęcie postępowania w sytuacji, gdy postanowienie o przedstawieniu zarzutów jedynie sporządzono, lecz go nie ogłoszono? We wskazanej kwestii stanowisko zajął R. A. Stefański (Stefański i in. 2004, 468-469). Uznał on, iż jedynie w sytuacji, gdy zaistnieją wskazane w art. $313 \S 1$ k.p.k. warunki, a więc gdy wydanego postanowienia nie ogłoszono i nie przesłuchano sprawcy z uwagi na ukrywanie się lub nieobecność w kraju, istnieje konieczność wznowienia postępowania. W pozostałych sytuacjach może zostać podjęte postanowienie o umorzeniu. Wniosek taki, zdaniem wskazanego autora, wypływa z brzmienia art. $313 \S 1$ k.p.k. Osobiście nie podzielam tego poglądu. Wydaje się, iż gwarancyjny charakter instytucji ,przedstawienia zarzutów", stypizowany w art. $313 \S 1$ k.p.k., ma prowadzić do niezwłocznego zapoznania podejrzanego z jego sytuacją procesową. Zaniechanie organów ścigania w tym przedmiocie działa na niekorzyść podejrzanego. Ponadto słuszne wydaje się przyjęcie, iż zgodnie z brzmieniem art. $71 \S 1$ k.p.k. osoba staje się stroną postępowania (podejrzanym) wówczas, gdy wydane zostanie postanowienie o przedstawieniu zarzutów (Tylman, Grzegorczyk 2010, 679; Stefański i in. 2004, $374-375)^{4}$. Poglądowi R. A. Stefańskiego można zarzucić, że prowadzi do niekonsekwencji. Można bowiem wedle tej konstrukcji podjąć postępowanie przeciwko osobie, w stosunku do której w poprzednim procesie wydano postanowienie o przedstawieniu zarzutów, nie ogłaszając go mimo możliwości, a następnie je umorzyć $\mathrm{w}$ istocie już przeciwko temu podmiotowi. Zauważyć należy, że nie tylko w pierwszym postępowaniu ograniczono konstytucyjne prawo podmiotu do obrony z winy organu procesowego, nie informując go o podjętych czynnościach, lecz także dodatkowo odmawia się mu ochrony płynącej z instytucji wznowienia (postanowienie Sądu Najwyższego z dnia 22 czerwca 2001 r., III KKN 44/01, LEX nr 51860) ${ }^{5}$. Wskazać tu należy na dwie dodatkowe okoliczności. Po pierwsze, jak wcześniej wspomniano, umorzenie postępowania $\mathrm{w}$ sprawie z powodu znikomej społecznej szkodliwości czynu nawet wówczas, gdy nie przedstawiono zarzutów, stwarza powagę rzeczy orzeczonej i jednocześnie uniemożliwia podjęcie postępowania. Druga okoliczność to konieczność zawężenia pola wznowienia

${ }^{4} \mathrm{~W}$ tym miejscu prowadzenie szczegółowych wywodów wydaje się niewłaściwe. Ograniczę się jedynie do stwierdzenia, iż optuję za rozumieniem „wydania postanowienia” ograniczającego się do jego sporządzenia i podpisania. Warto wskazać, że powołani autorzy odwołują się do bogatego piśmiennictwa - w szczególności zob. Stefański i in. 2004, 374-375.

${ }^{5}$ Sąd Najwyższy jeszcze na tle poprzedniego stanu prawnego wyraził pogląd, iż wszczęcie postępowania karnego przeciwko osobie o przestępstwo zarzucane jej w postanowieniu o przedstawieniu zarzutów następuje z datą jego wydania także wtedy, gdy z przyczyn niezależnych od organów ścigania (np. z powodu ucieczki lub ukrywania się podejrzanego) nie nastąpiło niezwłocznie ogłoszenie go osobie podejrzanej. Zob. też: Stefański 2002, 84-89. 
postępowania na rzecz jego podjęcia. Słuszne jest stanowisko, że nie można uznać za wszczęcie postępowania karnego in personam każdej czynności uprawnionego organu skierowanej wyraźnie na ściganie danej osoby z powodu określonego przestępstwa (Grzegorczyk 1997, 65; wyrok Sądu Najwyższego z 24 marca 1970 r., V KRN 52/70). Dlatego też należy zaaprobować pogląd, że występowanie w umorzonym postępowaniu „osoby podejrzanej” nie jest przeszkodą dla podjęcia postępowania, a następnie przedstawienia jej zarzutów (Tylman 1998, 81) ${ }^{6}$.

Trzeba podkreślić, że podjęcie postępowania umorzonego nie zostało przez ustawę ograniczone dodatkowymi terminami. Dlatego należy uznać, iż niedopuszczalność tego zabiegu wywołuje dopiero przedawnienie karalności (Szyprowski 1999, 16). Jak się wydaje, w obecnie obowiązującym stanie prawnym nie istnieje też początkowa cezura czasowa uzależniająca prawo podjęcia postępowania od chwili uprawomocnienia się postanowienia.

Jeśli chodzi o okoliczności uzasadniające podjęcie decyzji, to przepis art. 327 $\S 1$ k.p.k. milczy w tym zakresie. Również regulamin prokuratorski nie wskazuje okoliczności mogących uzasadniać taką decyzję. Jednak zgodnie z § 255 ust. 1 tego rozporządzenia, w uzasadnieniu postanowienia o podjęciu na nowo lub wznowieniu umorzonego postępowania należy wskazać okoliczności stanowiące podstawę jego wydania. W piśmiennictwie wskazuje się, iż takim warunkiem jest istnienie podstawy faktycznej, a więc takich uwarunkowań, które umożliwią stwierdzenie znamion przestępstwa, wykrycie sprawcy (Stefański i in. 2004, 471; Szyprowski 1999, 16; Prusak 1973, 53), a w konsekwencji doprowadzą do wniesienia aktu oskarżenia lub wniosku o warunkowe umorzenie postępowania (Młynarczyk 1995, 106; Tylman 1998, 82). Jakkolwiek nie jest wykluczone, iż czynności podjętego postępowania doprowadzą do kolejnego bezwarunkowego umorzenia postępowania. Do podjęcia postępowania wystarcza odmienna ocena prawna czy faktyczna sprawy, nie muszą ujawniać się nowe okoliczności (Gaberle 1972, 183)

Organem uprawnionym do podjęcia postępowania jest prokurator, który wydał lub zatwierdził postanowienie o umorzeniu postępowania. Słuszne jest stanowisko nakazujące uznanie, że nie istnieje obowiązek podjęcia decyzji przez tego samego prokuratora, który wydał poprzednia decyzję (Tomaszewski 1994, 32). Nie funkcjonuje tu bowiem zastrzeżenie, konieczności działania w tym samym składzie, który to warunek przez niektórych autorów wymagany jest na gruncie instytucji z art. 463 k.p.k. również w postępowaniu przygotowawczym. Decyzja może zostać podjęta - na zasadzie dewolucji - również przez prokuratora nadrzędnego lub Prokuratora Generalnego (Grzegorczyk 2008, 853; Stefański

${ }^{6} \mathrm{~W}$ piśmiennictwie wyrażono również odmienny pogląd, iż w żaden sposób nie można „wytoczyć" $\mathrm{z}$ art. 293 § 1 k.p.k. zakazu podjęcia na nowo postępowania przeciwko osobie podejrzanej, wobec której przeprowadzono wprawdzie w poprzednim postępowaniu określoną czynność na podstawie art. $206 \S 1$ (253 § 1 lub 267) k.p.k., jednak ani nie wydano postanowienia o przedstawieniu jej zarzutów, ani też nie przesłuchano jej w charakterze podejrzanego (Doda 1991, 84). 
i in. 2004, 472; Szyprowski 1999, 16; Tomaszewski 1994, 32-33; Włodyka 1963, 280). Słuszne jest również twierdzenie, że prokurator I instancji jest władny wydać postanowienie o podjęciu umorzonego postępowania również wówczas, gdy jego decyzja została utrzymana w mocy przez prokuratora nadrzędnego (argument a contrario z $\S 201^{1}$ ust. 2 regulaminu prokuratorskiego).

Prokurator uprawniony jest do podjęcia każdego umorzonego postępowania. Należy tu jednak wspomnieć o instytucji umorzenia rejestrowego. Oczywiście pamiętając o tym, że generalnie z uwagi na rodzaj czynów, jakich dotyczy ta forma umorzenia postępowania, zasadniczo nie dotyczy ona postępowań prowadzonych w ramach policyjnych Archiwów X. Mianowicie, jeżeli w toku czynności pozaprocesowych ujawnione zostaną dane pozwalające na wykrycie sprawcy, Policja może samodzielnie podjąć umorzone postępowanie (art. 325f $\S 3$ k.p.k.).

Należy się zgodzić Z. Młynarczykiem (1999, 16), iż mimo stylizacji przepisu, zgodnie z którym „postępowanie może być podjęte”, z zasady legalizmu wynika obowiązek określonego działania w sytuacji ujawnienia podstawy do podjęcia postępowania. Argumentację powyższą wspiera brzmienie $\S 255$ regulaminu prokuratorskiego, zgodnie z którym ,postanowienie o podjęciu na nowo umorzonego śledztwa, dochodzenia lub postępowania sprawdzającego należy wydać bezzwłocznie po ujawnieniu okoliczności wskazującej, że umorzenie postępowania było niezasadne bądź że postępowanie sprawdzające wymaga uzupełnienia”.

Decyzja o podjęciu postępowania zapada $\mathrm{w}$ formie postanowienia. Jest to orzeczenie niezaskarżalne (Stefański, Hofmański red. 2016). Zgodnie z $§ 256$ ust. 2 regulaminu prokuratorskiego o podjęciu na nowo i o wznowieniu umorzonego postępowania oraz podjęciu postępowania sprawdzającego zawiadamia się pokrzywdzonego i instytucję państwową, samorządową lub społeczną, która złożyła zawiadomienie o przestępstwie, zaś o wznowieniu - również podejrzanego. Wymóg zawiadomienia o treści podjętego postanowienia, a nie przesyłania odpisu postanowienia, wynika wprost z treści art. $100 \S 2$ k.p.k.

\section{WZNOWIENIE POSTĘPOWANIA PRZYGOTOWAWCZEGO}

W odróżnieniu od podjęcia postępowania elementem łączącym umorzone i wznowione postępowanie jest jego podmiot. Podstawowym celem tego zabiegu jest naprawa błędów, które wyniknęły z niepełnych ustaleń faktycznych (Gaberle 1972, 186).

Zgodnie z art. 327 § 2 k.p.k. „Prawomocnie umorzone postępowanie przygotowawcze wznawia się przeciwko osobie, która występowała w charakterze podejrzanego, na mocy postanowienia prokuratora nadrzędnego nad tym, który wydał lub zatwierdził postanowienie o umorzeniu, tylko wtedy, gdy ujawnią się nowe istotne fakty lub dowody nie znane w poprzednim postępowaniu albo gdy zachodzi okoliczność określona w art. $11 \S 3$ k.p.k. Przewidziane w ustawie 
ograniczenia okresu tymczasowego aresztowania stosuje się wówczas do łącznego czasu trwania tego środka".

Pierwszy element konstrukcji wznowienia postępowania, czyli konieczność istnienia relacji pomiędzy postępowaniami w postaci podmiotu, którego odpowiedzialności dotyczy postępowanie, jest oczywista. Wynika z tego, iż co do zasady ta instytucja nie znajdzie zastosowania dla wzruszenia postanowienia o umorzeniu ad rem ${ }^{7}$. Ta szczególna łączność podmiotowa powoduje, że obwarowanie instytucji wznowienia szeregiem ograniczeń jest zasadne (Kaftal 1971a, 21). Ograniczenia wyrażają się nie tylko w postaci określonych warunków, lecz także oddania decyzji o wznowieniu kontroli sądowej.

Warunkiem formalnym dla podjęcia decyzji jest istnienie materialnego substratu w postaci prawomocnego postanowienia o umorzeniu postępowania przygotowawczego. Przy rozpatrywaniu wznowienia należy się ograniczyć jedynie do pojęcia prawomocności. Cechę tą posiada również postanowienie wydane in personam, które nie może już zostać zaskarżone zwykłymi środkami odwoławczymi $^{8}$. Ma to miejsce w sytuacji:

- niezłożenia skutecznego środka odwoławczego,

- utrzymania w mocy decyzji przez organ ad quem,

- dopuszczalnej zmiany postanowienia przez organ ad quem.

Przepis art. 327 k.p.k. pozwala na wyróżnienie następujących podstaw dla wznowienia postępowania przygotowawczego:

- ujawnienie się nowych istotnych faktów lub dowodów nieznanych w poprzednim postępowaniu,

- wystąpienie okoliczności wskazanej w art. 11 § 3 k.p.k.

Druga podstawa wznowienia postępowania nie będzie omawiana $\mathrm{z}$ uwagi na fakt, iż zakres jej obowiązywania co do zasady nie łączy się z pracą policyjnych Archiwów X.

Ujawnienie się nowych istotnych faktów lub dowodów nieznanych w poprzednim postępowaniu. Należy zauważyć, iż w części dotyczącej określenia, co ma stanowić novum, ustawodawca w miejsce pojęcia „okoliczności”, które funkcjonowało w poprzednim stanie prawnym (k.p.k. z 1969 r.), przyjął określenie „fakty i dowody”. W piśmiennictwie poprzednio obowiązujące pojęcie wiązane było z uregulowaniem dotyczącym wznowienia postępowania sądowego i przewidzianej w art. 474 § 1 pkt. 2 k.p.k. z 1969 r. jego podstawie w postaci „nowych

${ }^{7} \mathrm{Tu}$ należy poczynić zastrzeżenie, iż w sytuacji umorzenia postępowania ad rem z powodu znikomej szkodliwości czynu może być uchylone w drodze wznowienia, gdyż niedopuszczalne jest tu podjęcie.

${ }^{8} \mathrm{~W}$ tym przedmiocie na uwagę zasługuje jedna z pierwszych wypowiedzi Sądu Najwyższego, która stanowiła przyczynek do dalszego rozwoju tej koncepcji. A mianowicie, w postanowieniu z dnia 10 grudnia 1957 r., I KO 285/57 (Śliwiński 1959, 80) sąd ten przyjął, iż postanowienie o umorzeniu postępowania staje się prawomocne po upływie terminu do wniesienia zażalenia lub po oddaleniu zażalenia albo pozostawieniu go bez rozpoznania. 
faktów i dowodów". Jeżeli związanie to było powszechne, to już rozumienie pojęcia „nowe fakty i dowody” budziło spore rozbieżności. Odpowiednio uznawano, iż uzasadniają wznowienie zarówno nowe źródła dowodowe, jak i nowe fakty dowodowe (A. Kaftal, F. Prusak), lub że tylko fakty dowodowe (A. Gaberle), czy też tylko nowe źródła dowodowe (A. Murzynowski) (Cieślak 1965, 381; Kaftal 1971b, 170; Kaftal 1971a, 24; Kaftal 1971c, 151-161; Młynarczyk 1999, 107; Gaberle 1972, 184-185; Murzynowski 1970, 1008). Choć aktualne rozwiązanie odbiega treściowo od znanego kodeksowi postępowania karnego z 1969 r., to jest zbieżne ze wskazanym już art. $474 \S 1$ pkt 2 k.p.k. z 1969 r., to aktualny pozostaje wydany na kanwie tego ostatniego przepisu wyrok Sądu Najwyższego z 19 stycznia 1974 r. (III KO 22/73, OSNKW z 1974 r. nr 6, poz. 120), zgodnie z którym nie tylko nowe źródło dowodowe spełnia wskazaną przesłankę, lecz również nieznany organowi środek dowodowy.

Kolejnym elementem składowym omawianej podstawy wznowienia postępowania jest konieczność stwierdzenia, że nowe fakty lub dowody są istotne. Niewątpliwie kolejne nieostre pojęcie użyte przez ustawodawcę musiało zostać dookreślone przez doktrynę. Wykształcone na jego gruncie stanowiska zależą od sposobu oceny tych okoliczności. I tak, dokonana ocena musi prowadzić do stwierdzenia, że umorzenie postępowania było błędem (Gaberle 1972, 187). Pierwszy sposób rozumienia istotności to stosowanie hipotetycznego rozumowania: „Jaki wpływ miałyby owe fakty i dowody, gdyby znane były w poprzednim postępowaniu?". Zgodnie z nim, jeżeli zapobiegłyby wydaniu postanowienia o umorzeniu postępowania, to posiadają wskazaną cechę „istotności” (Kaftal 1964, 756). Znacznie częściej tę cechę rozpatruje się ex post. Wówczas bada się, jaki wpływ na wyobrażenie o sprawie powodują podniesione fakty i dowody, i jeżeli w ich świetle postanowienie wydaje się bezzasadne, to oznacza to, iż są istotne (Waltoś 1965, 170; Gutkowska 1977, 29). Czasem podnosi się, że istotność polega nie tylko na podważeniu zasadności umorzenia, lecz także na stworzeniu prawdopodobieństwa wniesienia aktu oskarżenia (Młynarczyk 1999, 106-107; Tylman 1998, 82). Niezależnie od powyższego, nova, aby mogły zostać uznane za istotne, muszą być faktami prawdziwymi. Poważne trudności dowodowe, jakie niesie teza Sądu Najwyższego (uchwała Sądu Najwyższego z dnia 4 czerwca 1964 r., VI KO 10/64, „Państwo i Prawo” 1964, nr 1), pozwalają na uznawanie za zasadne, iż na etapie podejmowania decyzji o wznowieniu umorzonego postępowania wystarczające jest duże prawdopodobieństwo ich prawdziwości (Waltoś 1965, 170; Gaberle 1972, 196). Stąd konsekwencją ustalenia ich nieprawdziwości na dalszym etapie postępowania musi być umorzenie postępowania.

Uznaje się, iż nowe fakty muszą być ponadto nieznane w poprzednim postępowaniu. Teza ta wymaga doprecyzowania. Określenie „nieznane w poprzednim postępowaniu" oznacza, że były one nieznane organowi (noviter producta), a nie, że były nieznane również stronom (noviter repreta) (Grzegorczyk 2008, 855). Niewątpliwie dowodem nieznanym organowi jest dowód, który nie został wykryty 
lub znany był tylko stronie, a w konsekwencji nie był przeprowadzony w umorzonym postępowaniu. U podłoża tej koncepcji legło stwierdzenie, iż novum dowodu musi wynikać z luki w materiale dowodowym, a nie z jego błędnej oceny. W instytucji omawianej chodzi bowiem o stwierdzenie błędu braku wynikającego z nieprzeprowadzenia dowodu (Gaberle 1972, 186). Brak odzwierciedlenia konkretnego dowodu w materiale dowodowym musi skutkować uznaniem jego „nowości” w stosunku do organu. Z tego powodu słuszne są uwagi, że dowód, który nie został przeprowadzony w poprzednim postępowaniu, z uwagi na zakaz dowodowy, stanowi noviter producta 9 . Odmienne stanowisko prowadziłoby bowiem do stwierdzenia możliwości ujawnienia dowodu prawnie niedopuszczalnego. Ponieważ dowodem jest zarówno źródło dowodowe, jak i środek dowodowy, przeto warunek nowości spełnia zarówno nieznane dotąd źródło, jak i nowy, odmienny w swej treści, środek płynący ze znanego uprzednio źródła. Novum, aby było podstawą do wznowienia, musi też odpowiadać istotności dla procesu. Natomiast dowód znany organowi, ale nie ujawniony przez niego podczas orzekania, nie może stanowić podstawy dla wznowienia postępowania (Doda, Gaberle 1997, 534). Wyjaśnienia wymaga kwestia badania, czy dana okoliczność była znana w umorzonym postępowaniu przygotowawczym. Podstawę dla oceny tej przesłanki musi stanowić wiedza organu odzwierciedlona $\mathrm{w}$ aktach postępowania $\mathrm{w}$ chwili podejmowania decyzji.

Na podstawie powyższych kryteriów w piśmiennictwie ustalono następujące oceny co do niektórych dowodów w zakresie warunków, jakie muszą spełniać, aby mogły stanowić podstawę wznowienia prawomocnie umorzonego postępowania przygotowawczego:

1. Nowa ekspertyza (opinia) pozostająca w sprzeczności z ekspertyzą, na której organ procesowy oparł poprzednią decyzję stanowi przesłankę wznowienia wówczas, gdy ujawnia nowe istotne fakty dowodowe (Kaftal 1971a, 24-27).

2. Stwierdzenie, że zeznania świadka, na których oparto decyzję są fałszywe, stanowi nieznany istotny fakt i uzasadnia wznowienie postępowania (Gaberle 1972, 190).

3. Przyznanie się oskarżonego może stanowić podstawę dla wznowienia (Lipczyńska 1986, 230).

Nie mogą zostać uznane za spełniające wskazane warunki:

1. Odmienna ocena zeznań świadków (Młynarczyk 1999, 108).

2. Odmienna ocena dowodów w innym postępowaniu.

3. „Nowa norma prawna” w sytuacji wyprowadzania jej działania w drodze wykładni innych norm z uwzględnionego przez organ przepisu (Doda, Gaberle 1997, 534).

${ }^{9}$ Stanowisko takie wyrażone zostało w piśmiennictwie w związku z uchwałą Sądu Najwyższego z dnia 31 października 1975 r., II KO 19/75, OSPiKA 1976, nr 5, poz. 100, w którym to orzeczeniu sąd ten odmówił takiego przymiotu dowodowi nie przeprowadzonemu w umorzonym postępowaniu z uwagi właśnie na zakaz dowodowy. Krytycznie np.: Doda, Gaberle 1997, 535; Murzynowski 1976; Cieślak, Doda 1976, 74-75. 
Konstrukcja omawianej instytucji wymaga dla wznowienia postępowania, aby decyzję w tym zakresie podjął prokurator nadrzędny nad tym, który wydał lub zatwierdził postanowienie o umorzeniu postępowania (art. 327 § 2 k.p.k.). Brzmienie przepisu powoduje konieczność uznania, iż pełne kompetencje przysługują tylko i wyłącznie prokuratorowi nadrzędnemu. Prokurator, który wydał lub zatwierdził postanowienie o umorzeniu postępowania przygotowawczego, przekazuje pismo stanowiące wniosek do prokuratora nadrzędnego $\left(\S 201^{1} \S 3 \mathrm{zd}\right.$. pierwsze regulaminu prokuratorskiego). Nie posiada on tu zatem kompetencji do uwzględnienia takiego wniosku. Podobnie, lecz na podstawie stosowania zasady lex specialis derogat legi generali, należy wskazać, że to nie sąd, lecz prokurator nadrzędny posiada wyłączną kompetencję do podejmowania decyzji w przedmiocie wznowienia postępowania przygotowawczego (Stefański i in. 2004, 475).

Forma decyzji w przedmiocie wznowienia postępowania jest zależna od merytorycznej zawartości takiej czynności procesowej. O ile ustawa w art. $327 \S 3$ k.p.k. expressis verbis zastrzega konieczność wydania postanowienia o podjęciu lub wznowieniu postępowania, o tyle milczy w zakresie decyzji negatywnej dla wnioskodawcy. W piśmiennictwie (Gaberle 1972, 197) ukształtowanym jeszcze na gruncie k.p.k. z 1969 r. przyjmowano, że również taka decyzja wymaga formy postanowienia. I adekwatnie do tego przyjęcia decyzja taka, jako zamykająca drogę do wydania wyroku, byłaby zaskarżalna zażaleniem. Obecnie stosowny przepis regulaminu prokuratorskiego ( $\$ 256 \S 3 \mathrm{zd}$. drugie) stanowi, że ,,pismo informujące o braku podstaw do wydania postanowienia w trybie art. $327 \S 2$ k.p.k. powinno zawierać także informację o możliwości pozostawienia bez biegu następnych pism w tej sprawie, jeżeli nie zostaną przedstawione w nich nowe okoliczności uzasadniające wznowienie postępowania”. Takie ujęcie powoduje dopuszczalność różnicowania formy w zależności od merytorycznej zawartości czynności. Stwierdzenie, iż kolejne pismo może zostać pozostawione bez biegu, nie uprawnia do uznania, że może tego dokonać prokurator, który wydał zaskarżone orzeczenie. Wniosek taki wynika wprost z przyjęcia niemożności uchylenia normy ustawowej przez akt rzędu rozporządzenia. W dalszym zakresie obowiązuje tu zatem art. $327 \S 2$ k.p.k., uprawniający do działania w tym przedmiocie jedynie prokuratora nadrzędnego.

Postanowienie o wznowieniu unicestwia prawomocne postanowienie prokuratora o umorzeniu postępowania. $Z$ tej przyczyny zarówno bezzasadne, jak i niedopuszczalne jest wydawanie kolejnego postanowienia o uchyleniu tej decyzji. Takie stanowisko uzasadnione jest nie tylko poglądem piśmiennictwa (Stefański i in. 2004, 475), lecz również brakiem podstawy prawnej dla podjęcia wskazanej decyzji.

Postanowienie o wznowieniu postępowania nie jest zaskarżalne, zaś o jego treści zawiadamia się strony, lecz bez doręczenia im odpisu decyzji (art. $100 \S 2$ k.p.k.). Prawidłowo wznowione postępowanie powoduje powrót do uprawnień przez prowadzącego postępowanie. Władny jest on zatem podjąć każdą decyzję 
co do sposobu jego zakończenia. Jedyny swoisty powód umorzenia wbrew woli prowadzącego postępowanie stanowi obowiązek umorzenia postępowania, jeżeli przyjęte za podstawę decyzji nowe fakty lub dowody nie zostaną potwierdzone w toku postępowania wznowionego. Istnieje wówczas konieczność umorzenia postępowania (Waltoś 1965, 167-170).

Niezwykle istotnym aspektem dotyczącym wznowienia umorzonego postępowania jest udzielenie przez k.p.k. sądowi upoważnienia dla dokonania kontroli zasadności tej czynności. Bezzasadnie wznowione postępowanie podlega bowiem umorzeniu na podstawie art. $327 \S 4$ k.p.k. w zw. z art. $17 \S 1$ pkt 11 k.p.k. Jest to tzw. koncepcja konsumpcji skargi publiczne (Grzegorczyk 1980; Szyprowski 1999, 16-18).

Odnośnie do możliwości podejmowania czynności przed podjęciem postanowienia o wznowieniu postępowania decyduje art. 327 § 3 k.p.k. Pozostają tu aktualne rozważania poczynione na gruncie podjęcia postępowania, $\mathrm{z}$ tym jednak zastrzeżeniem, że jest niedopuszczalne przesłuchanie w jakimkolwiek charakterze osoby, przeciwko której postępowanie ma się toczyć. Zakres podejmowanych czynności powinien zostać ograniczony z uwagi na cel ich podejmowania. Art. $327 \S 3$ k.p.k. uprawnia bowiem do dokonania czynności, które potwierdzą istnienie podstaw dla wznowienia. Słuszne w tym względzie jest stanowisko, iż w sytuacji, gdy dążą one do potwierdzenia stawianego określonemu podmiotowi zarzutu, ich przeprowadzenie może naruszać prawo oskarżonego do obrony (Gutkowska 1977, 477).

Przedstawione instytucje znajdą zatem zastosowanie wówczas, gdy dojdzie do pozytywnego ustalenia możliwości ustalenia sprawcy w toku czynności podejmowanych przez funkcjonariuszy policyjnych Archiwów X.

\section{BIBLIOGRAFIA}

Cieślak, Marian. 1965. „Przegląd orzecznictwa Sądu Najwyższego w zakresie prawa karnego procesowego (I półrocze 1964 r.). Nowe Prawo 4.

Cieślak, Marian, Zbigniew Doda. 1976. „Przegląd orzecznictwa Sądu Najwyższego w zakresie postępowania karnego (I półrocze 1976 r.). Palestra 12.

Doda, Zbigniew. 1991. „Glosa do postanowienia SN z dnia 24 marca 1989 r., VI KZP 21/88”. Orzecznictwo Sąów Polskich 4: poz. 84.

Doda, Zbigniew, Andrzej Gaberle. 1997. Kontrola odwoławcza w procesie karnym. Warszawa: Dom Wydawniczy ABC.

Gaberle, Andrzej. 1972. Umorzenie postępowania przygotowawczego w polskim procesie karnym. Warszawa: Wydawnictwo Prawnicze.

Grzegorczyk, Tomasz. 1980. „Wygaśnięcie prawa oskarżyciela publicznego do oskarżania”. Problemy Praworządności 2. 
Grzegorczyk, Tomasz. 1997. Strony, ich procesowi przedstawiciele i inni uczestnicy postępowania karnego. Warszawa: Wydawnictwo Prawnicze.

Grzegorczyk, Tomasz. 2008. Kodeks postępowania karnego. Komentarz. Warszawa: Wolters Kluwer. Gutkowska, Elżbieta. 1977. „Problematyka ponownego wszczęcia umorzonego postępowania przygotowawczego". Problemy Praworządności 1977: 7-35.

Kaftal, Andrzej. 1959. „Na marginesie noweli do k.p.k. z dnia 18 czerwca 1959 r.”. Nowe Prawo 9.

Kaftal, Andrzej. 1964. „O ponownym wszczęciu prawomocnie umorzonego postępowania karnego”. Stużba MO 2.

Kaftal, Andrzej. 1971a. „Kontrola prawomocnych orzeczeń w postępowaniu przygotowawczym”. Problemy Praworządności 5.

Kaftal, Andrzej. 1971b. Kontrola prawomocnych orzeczeń w polskim procesie karnym. Warszawa: Wydawnictwa Uniwersytetu Warszawskiego.

Kaftal, Andrzej. 1971c. „Glosa do wyroku 7 sędziów z dnia 20 lutego 1969 r.”. Państwo i Prawo 5.

Kulesza, Monika. 1960. „Podjęcie i wznowienie umorzonego śledztwa lub dochodzenia”. Stużba MO 5 .

Kurowski Michał, Dariusz Świecki, Barbara Augustyniak, Krzysztof Eichstaedt. 2015. Kodeks postepowania karnego. Komentarz. Warszawa: Wolters Kluwer.

Lipczyńska, Monika, Ryszard Ponikowski. 1986. Mały komentarz do kodeksu postępowania karnego. Warszawa: PWN.

Młynarczyk, Zbigniew. 1995. „Nadzór prokuratora nad postępowaniem przygotowawczym. Akt oskarżenia”. Prokuratura i Prawo 10.

Murzynowski, Andrzej. 1970. „Podstawy wznowienia postępowania”. Nowe Prawo 7-8.

Murzynowski, Andrzej. 1976, „Glosa do uchwały SN z dnia 31 października 1975 r., II KO 19/75. Orzecznictwo Sądów Polskich i Komisji Arbitrażowych 5: poz. 100.

Prusak, Feliks. 1973. Pociagnięcie podejrzanego do odpowiedzialności w procesie karnym. Warszawa: Wydawnictwo Prawnicze.

Stefański, Ryszard. 2002. „Glosa do postanowienia Sadu Najwyższego z dnia 22 czerwca 2001 r., III KKN 44/01". Prokuratura i Prawo 5.

Stefański, Ryszard, Jerzy Bartoszewski, Lech Gardocki, Zbigniew Gostyński, Stanisław M. Przyjemski, Ryszard A. Stefański, Stanisław Zabłocki. 2004. Kodeks postępowania karnego. Komentarz. Warszawa: Wolters Kluwer.

Stefański, Ryszard, Piotr Hofmański (red.). 2016. System Prawa Karnego Procesowego. T. X. Postepowanie przygotowawcze. Warszawa: Wolters Kluwer.

Szyprowski, Bartłomiej. 1999. „Kontrola prawomocnych orzeczeń wydanych w postępowaniu przygotowawczym". Prokuratura i Prawo 9.

Śliwiński, Stanisław. 1959. „Przegląd orzecznictwa SN (prawo karne procesowe - IV kwartał 1958 r.)". Państwo i Prawo 7.

Tomaszewski, Paweł. 1994. „Niektóre problemy związane z podjęciem na nowo prawomocnie umorzonego postępowania przygotowawczego". Wojskowy Przegląd Prawniczy 3-4.

Tylman, Janusz. 1998. Postepowanie przygotowawcze w procesie karnym. Warszawa: Wydawnictwo Prawnicze.

Tylman Janusz, Tomasz Grzegorczyk. 2010. Polskie postepowanie karne. Warszawa: LexisNexis.

Waltoś, Stanisław. 1965. „Glosa do uchwały SN z dnia 4 czerwca 1964 r., VI KO 10/64. Państwo i Prawo 1 .

Włodyka, Stanisław. 1963. Organizacja wymiaru sprawiedliwości PRL. Warszawa: PWN. 
Michat Kurowski

\title{
THE INSTITUTION OF INSTIGATING AND REOPENING DISCONTINUED PREPARATORY PROCEEDINGS AS A METHOD TO TERMINATE PROCEEDINGS BECAUSE OF DETECTION ACTIVITIES UNDERTAKEN BY THE POLICE X ARCHIVES
}

\begin{abstract}
The institutions of reopening and instituting discontinued preparatory proceedings are of the key importance as regards a possibility of returning to criminal proceedings already finished. Principles of criminal proceedings deciding how to conduct them in certain circumstances force completion of the proceedings at a given stage. Sometimes this is due to the appearance of a relative, therefore removable, negative procedural condition, sometimes due to the impossibility of detecting perpetrators of the offence. It is therefore crucial to establish what conditions to return to the discontinued preparatory proceedings are. Is it possible? What is the time frame for a decision to be made? This study provides answers to the problems identified, focusing obviously on the procedural conditions of admissibility of the return to criminal proceedings. The rules have been laid down in the law system according to the time of proceedings completion. The article also presents such elements as bodies authorised to act, conditions of the prosecutor's operations, a role and a place of the Police in the decision-making system. The mentioned elements are an attempt to locate these particular institutions in the system of revealing some old crimes committed by perpetrators not yet disclosed.
\end{abstract}

Keywords: criminal proceedings, instigating proceedings, reopening discontinued preparatory proceedings, procedural conditions. 